\title{
Comparison of Academic Suspension Levels of Faculty of Sports Sciences Students and Faculty of Education Students
}

\author{
Latif Aydos ${ }^{1, *}$, Haluk Koç ${ }^{1} \&$ Hacı Ahmet Pekel ${ }^{1}$ \\ ${ }^{1}$ Sport Sciences Faculty, Gazi University, Ankara, Turkey \\ *Correspondence: Sport Sciences Faculty, Gazi University, Turkey. E-mail: Latifaydos@Gmail.Com
}

Received: May 6, $2018 \quad$ Accepted: June 21, $2018 \quad$ Online Published: July 13, 2018

doi:10.5430/wje.v8n4p1 URL: https://doi.org/10.5430/wje.v8n4p1

\begin{abstract}
In this study, the academic suspension levels of the students of the Faculty of Sports Sciences students and the Faculty of Education students in terms of age, gender, active sports making, department, graduated high school, mother education level, father education level, mother profession and father occupation variables have been examined. A total of 364 university students studying in the Faculty of Sport Sciences and the Faculty of Education in Gazi University, Hacettepe University and Ankara University were formed the Research group in the academic years 2017-2018. The Academic Suspension Scale developed by Çakıcı in 2003 was used in the study. It was compared average scores in unrelated measures, Variance Analysis (one-way ANOVA, independent sample t-test) for comparison of mean scores in unrelated measures, the Tukey test to determine which groups had significant differences were used. In addition, a Pearson Correlation analysis was conducted to test the relationship between the particles collected in the single sub-dimension. Findings obtained from this research reveal that the students of Faculty of Sports Sciences showed more academic suspension behaviors than the students of Faculty of Education.
\end{abstract}

Keywords: academic suspension, sport, education, higher education

\section{Introduction}

Suspension can be defined that the tasks are delayed unnecessarily that are appropriate to be completed by going into action and as a result of this situation, that the individual tends to complete the task he delays when the individual feels saddened at a high level (Solomon \& Rothblum, 1984) or tasks are delayed until the moment it is needed to be done and the individual is exposed to undesirable negative consequences due to such delayed behavior (Neenan, 2008). The noteworthy common theme in the definitions of suspension is the notion of "suspension", but there are different opinions as to whether each deferral is suspension. At this point, if the individual is delaying at the level of habit and is therefore exposed to internal and external adverse outcomes, this seems to be defined as suspension (Burka \& Yuen, 2008; Ferrari, Johnson \& McCown, 1995).

According to Ellis and Knaus (1979), who explain the reasons for procrastination, procrastination is a rational thought that an individual possesses. Authors consider procrastination an emotional disturbance originating from non-rational thinking. One of the basic rational beliefs that lead to procrastination is the idea that "I must do my best" to prove the thought of "I am a precious human being". In such a situation, when the individual inevitably fails to do the best, his unruly beliefs lay the groundwork for a low self-esteem.

Another researcher who mentioned irrationality while explaining the behavior of procrastination is Lay (1986). The author mentions about the pressure factor and put forwards that the person making procrastination underestimates the time required to complete the task and tends to make the time to be unrealistic and irrational. The tendency to underestimate in individuals with procrastination occurs when they are under the pressure of the delivery date, and when they come under pressure by other attractive tasks rather than studying the duty at hand. Another possibility that Lay (1986) put forwards that the person making procrastination tend to increase the time needed to complete the task. As a result, if the individual is prone to cognitive distortion related to the time required (person may underestimate the time or increase the time needed) individual may be reluctant to start and complete the task. It is the irrationality of the individuals making procrastination, especially regarding the completion period of the task.

Procrastination, which negatively affects the internal and interpersonal functioning of an individual, is classified in 
different form. It is noteworthy that procrastinations was classified in two different types namely personality trait and situational postponement. It is defined as the individual procrastinates to start or to complete a duty in different areas of life as the personality traits, and in a certain area of life as situational procrastination (Ferrari, O'Callaghan \& Newbegin, 2005). The most common type of situational procrastination is academic procrastination (Senecal, Lavoie \& Koestner, 1997). Since procrastination is particularly intense in the academic field, (Motie, Heidari \& Sadeghi, 2012; Rosario et al., 2009) academic procrastination is a type of procrastination that attracts more researchers' attention and becomes subject matter for researches frequently (Milgram, Gehrman \& Keinan, 1992).

It is put forward that suspension is common among university students in terms of academic special duties (Burka \& Yuen, 2008; Ellis \& Knaus, 1979; Kachgal, Hansen \& Nutter, 2001; Rothblum et al., 1986). At the same time, it is expressed as a universal concept that negatively affects student achievement, especially in the academic field (Motie et al., 2012).

It is noteworthy that delaying academic responsibilities at the level of habits led to some negative academic outcomes and some mental health problems such as depression and anxiety. Academic problems caused by academic delays include dropping out the course, low course scores (Semb, Glick \& Spencer, 1979), missing the due date of the assignment (Beswick, Rothblum \& Mann, 1988), delayed preparation for examinations, (Baumeister, Heatherton \& Tice, 1994), less study and lower academic performance for the exam, (Beck, Knoos \& Milgram, 2000; Rothblum et al., 1986) academic stress (Sharma \& Kaur, 2011), exhibiting performance below the capacity together with experiencing intense stress (Baumeister, Heatherton \& Tice, 1994), the decrease in academic life satisfaction (Balk1s, 2013). It is suggested, however, that those who suspended in the academic field report much more stress and much more illness compared to those who do not. (Tice \& Baumeister, 1997), it is suggested that depression and anxiety levels were higher (Beswick et al., 1988; Saddler \& Sacks, 1993; Senecal, Koestner \& Vallerand, 1995; Soloman \& Rothblum, 1984). Considering the negative results of the individual's academic life and mental health, it seems that the suspension tendency in the academic field has a harmony disturbing and nonfunctional structure.

The aim of this research is to determine the levels of academic suspension existing in educational lives of the university students. For this purpose, differentiation situations of the academic suspension levels of the students who are studying in different parts of the universities have been investigated according to sex, doing active sports and age.

\section{Method}

In this study, relational search method was used in order to reach the findings about the difference between academic suspension scores of sex, age, active sports making, department, graduated high school, mother education level, father education level, mother profession and father occupation variables.

\subsection{Study Group}

A total of 364 university students studying in the Faculty of Sport Sciences and the Faculty of Education in Gazi University (n:150), Hacettepe University (n:114) and Ankara University (n:100) formed the research group of the study in the academic years 2017-2018. Demographic information of university students are given in Table 1.

\subsection{Data Collection Tool}

The Academic Suspension Scale used in the study was developed by Çakıcı (2003). This scale is composed of 19 expressions in total including 12 negative expressions $(2,3,5,6,8,10,12,14,15,16,18,19), 7$ positive expressions $(1,4,7,9,11,13,17)$ including the tasks they are responsible for in their learning such as studying lesson, preparing for exams, preparing the project. Responses to these expressions are rated in the five-digit Likert type, including "not reflecting me at all", "reflecting me very little", "reflecting me a little", "mostly reflecting me", "completely reflecting me". Scale is scored as one way so as to get 1 by those marking the choice of "not reflecting me at all", to get 5 by those marking the choice "completely reflects me" in an expression with academic suspension. The highest score to be taken from the scale is 95 and the lowest score is 19 . The high score obtained from the scale indicates that students exhibit academic suspension behavior (Çakıc1, 2003). The Cronbach alpha reliability coefficient of the Academic Suspension Scale was found as 92. While the Cronbach's alpha coefficient calculated for Factor 1 of the scale is 89 , the Cronbach's alpha coefficient calculated for Factor 2 is 84 . Spearman Brown two half test reliability was calculated as .85 in total, including for the first half test of 10 items, 87,9 and for the second half of the test 86 . As a result, it is seen that the Academic Suspension Scale used in this study fulfilled the validity and reliability criteria as a result of the validity and reliability studies conducted. 


\subsection{Analysis of Data}

In the analysis of the data collected by the researchers; frequency and percentage for the demographic characteristics of students; descriptive statistics on academic suspension scores; to compare average scores in unrelated measures, Variance Analysis (one-way ANOVA, independent sample t-test) for comparison of mean scores in unrelated measures, the Tukey test to determine which groups had significant differences were used. In addition, a Pearson Correlation analysis was conducted to test the relationship between the particles collected in the single sub-dimension. The Statistics Program (SPSS 23.0) was used in the analyzes.

\section{Result}

In this section, findings related to the demographic characteristics of the students included in the sampling group were examined; findings regarding the differences between the groups in terms of gender, age, active sports making, department, graduated high school, mother education level, father education level, mother profession and father occupation variables were included in the academic suspension points.

Table 1. Demographic Information of Students Studying at the Faculty of Sport Sciences and Faculty of Education.

\begin{tabular}{|c|c|c|c|c|c|c|c|c|c|c|}
\hline \multirow[t]{2}{*}{ Faculty } & \multicolumn{2}{|c|}{ Gender } & \multicolumn{2}{|l|}{ Age } & \multicolumn{2}{|c|}{ Active Sports } & \multicolumn{2}{|c|}{ Department } & \multicolumn{2}{|c|}{$\begin{array}{c}\text { Graduated high } \\
\text { school } \\
\end{array}$} \\
\hline & $\mathrm{N}$ & $\%$ & $\mathrm{~N}$ & $\%$ & $\mathrm{~N}$ & $\%$ & $\mathrm{~N}$ & $\%$ & $\mathrm{~N}$ & $\%$ \\
\hline \multirow{7}{*}{$\begin{array}{l}\text { Sports } \\
\text { Science }\end{array}$} & Women:55 & 70.1 & 18-20: 47 & 25.5 & Yes:118 & 64.1 & Physical & 34.8 & Anatolian: 83 & 45.1 \\
\hline & Men:129 & 29.9 & 21-23: 90 & 48.9 & No: 66 & 35.9 & Education: 64 & 32.6 & Science: 4 & 2.2 \\
\hline & & & $24-26: 30$ & 16.3 & & & With Trainer: 60 & 3.3 & Vocational: 34 & 18.5 \\
\hline & & & 27-30: 11 & 6 & & & Management: 6 & 29.3 & Sports: 8 & 4.3 \\
\hline & & & Over 30-: 6 & 3.3 & & & Recreation: 54 & & Other: 55 & 29.9 \\
\hline & \multicolumn{2}{|c|}{ Mother education } & \multicolumn{2}{|c|}{ Father education } & \multicolumn{2}{|c|}{ Mother occupation } & \multicolumn{2}{|c|}{ Father occupation } & & \\
\hline & $\mathrm{N}$ & $\%$ & $\mathrm{~N}$ & $\%$ & $\mathrm{~N}$ & $\%$ & $\mathrm{~N}$ & $\%$ & & \\
\hline \multirow[t]{15}{*}{ Faculty } & Elementary & 39.1 & Elementary & 26.6 & Official: 14 & 7.6 & Official: 24 & 13 & & \\
\hline & School: 72 & 25 & School: 49 & 13.6 & Worker: 16 & 8.7 & Worker: 37 & 20.1 & & \\
\hline & Secondary & 25.5 & Secondary & 39.7 & Artisan: 7 & 3.8 & Artisan: 37 & 20.1 & & \\
\hline & School: 46 & 2.2 & School: 25 & 3.3 & Retired: 9 & 4.9 & Retired: 51 & 27.7 & & \\
\hline & High School: & 8.2 & High school: & 16.8 & Nonworking:1 & 62 & Nonworking: 6 & 3.3 & & \\
\hline & 47 & & 73 & & 14 & 13 & Other: 29 & 15.8 & & \\
\hline & Undergraduat & & Undergraduate & & Other: 24 & & & & & \\
\hline & e: 4 & & $: 6$ & & & & & & & \\
\hline & Master: 15 & & Master: 31 & & & & & & & \\
\hline & Gende & & Age & & Active Sp & & Departm & & $\begin{array}{r}\text { Graduated } \\
\text { Schoo } \\
\end{array}$ & \\
\hline & $\mathrm{N}$ & $\%$ & $\mathrm{~N}$ & $\%$ & $\mathrm{~N}$ & $\%$ & $\mathrm{~N}$ & $\%$ & $\mathrm{~N}$ & $\%$ \\
\hline & Women: 153 & 85 & 18-20: 73 & 40.6 & Yes: 50 & 27.8 & Science:75 & 41.7 & Anatolian: 86 & 47.8 \\
\hline & Men:27 & 15 & 21-23: 101 & 56.1 & No: 130 & 72.2 & Mathematics: & 58.3 & Science: 7 & 3.9 \\
\hline & & & 24-26: 6 & 3.3 & & & 105 & & Vocational: 7 & 3.9 \\
\hline & & & & & & & & & Other: 80 & 44.4 \\
\hline \multirow{11}{*}{$\begin{array}{l}\text { Education } \\
\text { Faculty }\end{array}$} & \multicolumn{2}{|c|}{ Mother education } & \multicolumn{2}{|c|}{ Father education } & \multicolumn{2}{|c|}{ Mother occupation } & \multicolumn{2}{|c|}{ Father occupation } & & \\
\hline & $\mathrm{N}$ & $\%$ & $\mathrm{~N}$ & $\%$ & $\mathrm{~N}$ & $\%$ & $\mathrm{~N}$ & $\%$ & & \\
\hline & Elementary: & 41.7 & Elementary: & 22.2 & Official: 18 & 10 & Official: 47 & 26.1 & & \\
\hline & 75 & 14.4 & 40 & 16.1 & Worker: 13 & 7.2 & Worker: 37 & 20.6 & & \\
\hline & Secondary & 33.3 & Secondary & 32.8 & Retired: 7 & 3.9 & Artisan: 21 & 11.7 & & \\
\hline & School: 26 & 6.7 & School: 29 & 16.7 & Nonworking:1 & 70.6 & Retired: 46 & 25.6 & & \\
\hline & High School: & 3.9 & High School: & 12.2 & 24 & 8.3 & Nonworking: 5 & 2.8 & & \\
\hline & 60 & & 39 & & Other: 15 & & Other: 24 & 13.3 & & \\
\hline & Undergraduat & & Undergraduate & & & & & & & \\
\hline & e: 12 & & $: 30$ & & & & & & & \\
\hline & Master:7 & & Master: 22 & & & & & & & \\
\hline
\end{tabular}


When Table 1 is examined, it is seen that there are 184 students in the Faculty of Sports Sciences and 180 students in the Faculty of Education. It is seen that there are at 18-20 age range 21-23 age range 90 students (48.9\%), at 24-26 age range $30(16.3 \%)$, at 27-30 age range $11(6 \%$ (3.3\%) students; $118(64.1 \%)$ active sports doing students, 66 $(35.9 \%)$ non active students in the Faculty of Sports Sciences; $64(34.8 \%)$ who study in physical education and sports teacher department, $60(32.6 \%)$ in the trainer section, $6(3.3 \%)$ in the management section and $54(29.3 \%)$ in the recreation section.

It is seen that there are at 18-20 age group 73 (40.6\%), 21-23 age group $101(56.1 \%), 24-26$ age group $30(6 \%)$ students; $50 \%$ (27.8) active sports doing students, 130 (72.2\%) non active sportsmen in the Faculty of Education; 75 (41.7\%) students in the science department and 105 (58.3\%) students in the mathematics department

Table 2. Differences in Academic Suspension Scores of Students Attending the Faculty of Sports Sciences and Faculty of Education by Gender Variable ( $t$ test)

\begin{tabular}{llcccccc}
\hline Sub dimension & \multicolumn{1}{c}{ Faculty } & Gender & $\mathbf{N}$ & $\overline{\boldsymbol{X}}$ & Ss & $\mathbf{T}$ & $\mathbf{p}$ \\
\hline \multirow{3}{*}{ Academic } & Faculty of Sports & Women & 55 & 53.400 & 15.121 & 2.282 & $.024^{*}$ \\
Suspension & Science & Men & 129 & 58.294 & 12.483 & & \\
& Faculty of & Women & 153 & 57.259 & 14.179 & 1.367 & .173 \\
& Education & Men & 27 & 53.745 & 11.965 & & \\
\hline
\end{tabular}

$\mathrm{p}<.05^{*}$

When Table 2 was examined, it was found that there was a statistically significant difference between the average suspension scores of the students who were educated at the Faculty of Sports Sciences $(p<.05)$. No significant difference was found for the Faculty of Education students $(\mathrm{p}>.05)$. According to findings, male students $(\mathrm{X}=$ $58.294 \pm 12.483)$ showed more meaningful opinion than female students $(X=53.400 \pm 15.121)$ in academic suspension points.

Table 3. Differences in Academic Suspension Scores According to the Variables of Active Sporting Activities of the Students in the Faculty of Sport Sciences and Faculty of Education. (t test)

\begin{tabular}{llllllll}
\hline Sub dimension & Faculty & Active Sports & $\mathbf{N}$ & $\overline{\boldsymbol{X}}$ & Ss & $\mathbf{T}$ & $\mathbf{P}$ \\
\hline \multirow{3}{*}{ Academic } & Faculty of Sports Science & Yes & 118 & 57.754 & 12.089 & 1.244 & .215 \\
& & No & 66 & 55.181 & 15.609 & & \\
Suspension & Faculty of Education & Yes & 50 & 55.260 & 13.396 & .665 & .507 \\
& & No & 130 & 53.892 & 11.946 & & \\
\hline
\end{tabular}

$\mathrm{p}>.05$

When Table 3 was examined, it was found that there was no statistically significant difference between the academic average suspension scores of the students who were educated at the Faculty of Sports Sciences and at the Faculty of Education ( $\mathrm{p}>.05)$.

Table 4. Differences in Academic Suspension Scores According to Age Variables of Students in Sports Sciences and Education Faculties (One Way ANOVA)

\begin{tabular}{|c|c|c|c|c|c|c|c|c|c|c|}
\hline $\begin{array}{l}\text { Sub } \\
\text { dimension }\end{array}$ & Faculty & Age & $\mathbf{N}$ & $\bar{X}$ & $\begin{array}{ll}\text { Source of } \\
\text { variance }\end{array}$ & $\begin{array}{l}\text { Sum of } \\
\text { squares }\end{array}$ & Ss & $\mathbf{F}$ & $\mathbf{p}$ & $\begin{array}{l}\text { Source } \\
\text { difference }\end{array}$ \\
\hline Academic & & $18-20$ & 47 & 58.29 & Inter groups & 1242.60 & 4 & & & \\
\hline \multirow[t]{9}{*}{ suspension } & & $21-23$ & 90 & 57.90 & & & & & & \\
\hline & Sports & $24-26$ & 30 & 55.50 & & & & & & \\
\hline & Sciences & $27-29$ & 11 & 50.90 & Intra Groups & 31975.17 & 179 & 1.739 & .143 & \\
\hline & & Over 30- & 6 & 46.83 & & & & & & \\
\hline & & Total & 184 & 56.83 & Total & 33217.77 & 183 & & & \\
\hline & & $18-20$ & 73 & 54.19 & Inter groups & 1074.00 & 2 & 33.628 & & $24-26 * 18-20$ \\
\hline & Education & $21-23$ & 101 & 55.09 & Intra Groups & 26197.58 & 177 & & $.029 *$ & $224-26 * 21-23$ \\
\hline & & $24-26$ & 6 & 41.33 & & & & & & \\
\hline & & Total & 180 & 54.27 & Total & 27271.66 & 179 & & & \\
\hline
\end{tabular}

$p<.05^{*}$ 
When Table 4 was examined, it was found that there was a significant difference $[F(2,177)=3,628, p<.05]$ between the mean of academic suspension points according to the age variable of the students in the Faculty of Education. There was no significant difference in other sub-dimensions according to age ( $\mathrm{p}>.05)$.

According to multiple comparison test results, there is a significant difference between 24-26 years, 18-20 years and 21-23 years according to the academic suspension scores in assessing the age status of students $(\mathrm{p}<.05)$. The average score of the answers given between the ages of 18-20 is 54,19, the average score of the answers given by $21-23$ age is 55,09 .

There was no significant difference in the one-way ANOVA results between the academic suspension scores according to high school, department, mother education level, father education level, maternal profession and father occupation variables of students graduated from Sports Sciences and Education Faculties ( $p>.05)$.

Table 5. Mean $(\overline{\mathbf{X}})$ and Standard (ss) Values of the Academic Suspension Structure of the Students at the Faculty of Sport Sciences and Faculty of Education.

\begin{tabular}{lllrl}
\hline Dimension & Department & N & $\overline{\boldsymbol{X}}$ & Ss \\
\hline Academic & Faculty of Sports Science & 184 & 56.831 & 13.472 \\
Suspension & Faculty of Education & 180 & 54.272 & 12.343 \\
& Total & 364 & 55.565 & 12.972 \\
\hline
\end{tabular}

When Table 5 is examined, it is seen that the academic suspension behaviors of the students of the Faculty of Sports Sciences are higher than the ones of the Education Faculties according to the one dimensional academic suspension of the scale.

In addition, a Pearson Correlation analysis was performed to test the relationship between the groups and the items collected in the single sub-dimension. It has been founded that there was a positive and significant relationship between the groups and the academic procrastination items at low level as a result of the Pearson Correlation analysis with $95 \%$ reliability that was obtained by taking the average of the items in the single sub-dimension [r $(364)=.099 ; \mathrm{p}<.01]$.

\section{Discussion and Conclusion}

In this study, it was investigated whether there a significant difference between the academic postponement scores in accordance with gender, age, active sports doing, high school, department, mother education level, father education level, mother profession and father occupation variables of the students who are educated in Faculty of Sports Sciences and Faculty of Education. As a result of the analyzes, it was determined that there is a significant difference in gender and age variables

It has been determined that there is a significant differentiation in favor of the male students who are educated in the Faculty of Sports Sciences as a result of the analysis aimed to reveal the difference of the academic suspension tendencies of the university students according to the gender variable. That is to say, men have exhibited more academic suspension behavior than girls. When the literature is examined, it is seen that there are some research findings supporting the study (Akdoğan, 2013; Balkıs \& Duru, 2009; Berber Çelik \& Odacı, 2015; Çakıc1, 2003; Flett, Blankstein, Hewitt \& Koledin, 1992; Kandemir, 2010; Prohaska et al., 2000; Senecal et al., 1995; Uzun Özer, 2005; Yeşil \& Şahan, 2012; Zakeri, Esfahani \& Razmjoee, 2013); while others do not seem to support it (Aydoğan, 2008; Ekşi \& Dilmaç, 2011; Kim \& Seo, 2015; Uzun Ozer \& Topkaya, 2011; Watson, 2001; Yiğit \& Dilmaç, 2015). According to Karakitapoğlu-Aygün (2004), while it is expected to be more independent, more autonomous and higher in terms of achievement orientation than men in the Turkish family structure, more relational, more emotional and care-oriented social roles than females are expected; more relational, more emotional and caring practices priority social roles are expected from girls. Therefore, unlike traditional gender roles, girls may be expected to show less academic suspension behavior due to their high academic success and motivation to differentiate themselves. In addition, according to Jackson $(2002 ; 2003)$ it may be considered that academic duties such as making homework in school life and preparing for exams are perceived more as feminine works by male students and those male students may avoid academic duties in order to be labeled as feminine and may procrastinate these duties regularly. Obtaining different results of studies examining the relationship between academic suspension behavior and gender may be due to the cultural differences of the samples examined. However, it is believed that further deeper study is needed to clarify the relationship between academic suspension and gender. 
It has been determined that there is a significant differentiation in favor of students between 24-26 years of education in the Faculty of Education as a result of the analysis aimed to reveal the difference of academic suspension of tendencies of university students according to age, That is to say, students between the ages of 24-26 showed more academic suspension behavior than the 18-20 and 21-23 age groups. It is seen that there are some research findings supporting the study (Aydogan \& Özbay, 2012; Balkıs, 2006); while others do not seem to support it (Akkaya, 2007; Ekşi \& Dilmaç, 2011; Uzun-Özer \& Topkaya, 2011). In some studies, it was determined that the behavior of academic suspension was examined according to class level. The results obtained from these studies also support the results of the research when it is thought that the class progresses in direct proportion to the increasing of the age (Balkıs, 2007; Rosario, Costa, Nunez \& Gonzales-Pienda, 2009). According to these studies, as the class level gets higher, that is to say, the age gets increased, the tendency of academic suspension increases as well. Ferrari and Scher (2000) point out that mastering learning skills leads students to show more suspension behavior in academic works. Similarly, in the study McCown and Roberts (1994) carried out with 1543 student, they have examined the prevalence of procrastination tendency of university students. As a result of the research, it was reported that $19 \%$ of the students in the first class, $22 \%$ of the students in the second class, $27 \%$ of the students in the third class and $31 \%$ of the students in the fourth class show academic procrastination behavior. It has been seen that as the class level increases, the tendency of procrastination increases as well. In the first years of university education students are concerned that they will not succeed in the environment they are new to. Academic duties may remain at the forefront for the students in the first years of the university and they may do these tasks regularly on time without delay. Whereas, in later grades, students become accustomed to academic life, better adapt to teaching and teaching approaches, and their anxiety is reduced. Therefore, they can be more comfortable to delay their academic duties. Furthermore, students who are in the last year of education, that is, those with an increasing age, experience an uncertainty about how they will continue their lives after graduation, and it may lead to them more to show more suspension behavior.

As a result of the analysis aimed to reveal the difference of the academic suspension tendencies of the university students according to the department studied, no significant difference was found between the groups. This result overlaps with the conclusion of Berber-Celik and Odac1 (2015) on the different departments. Some studies have found that there is a meaningful difference between students' academic suspension levels and the departments they have studied (Pala, Akyıldız \& Bağcı, 2011; Eksi \& Dilmaç, 2011; Karabıyık-Çeri, Çavuşoğlu \& Gurol, 2015). As a result of exhibiting academic suspension behavior according to the department; it can be said that the students prefer departments while they do not fall into the area of interest unconsciously and so they have low motivation because they have to work in a field that does not attract their attention. The departments preferred by the students may not be appropriate for the level of cognitive development of the students, it can be said that this situation causes differentiation of the students' academic suspension behavior according to faculty type. As a result of this study, it is seen that the students prefer the departments that are suitable for their interests and their cognitive development.

As a result of the analysis made in order to show the difference of academic suspension tendencies of university students according to father education status and mother education status variables, no significant difference was found between the groups. In the studies carried out by Balkıs (2006) and Arslan (2013), the result that the students' academic suspension tendencies did not make a difference according to the variables of education level of mother and father, shows parallel with this study. The result of not being difference in the academic suspension behavior of the father education overlaps with the results of Teyfur et al. (2017). In the findings of Yiğit and Dilmaç (2011), the academic suspension scores did not differ according to the education level of the mother, however, in accordance with the father's educational status variable, it was seen that academic suspension points of the students, whose fathers were graduated from primary, school were significantly higher than the academic suspension scores of the students, whose fathers were graduated from high school and university. In the study of Balkis (2006), the reason why teacher candidates do not show differentiation between the academic tendency levels according to their father and mother's education level is that parents should not have a numerical sense of equality between their levels of education.

As a result of the analysis aimed to reveal the difference of academic suspension tendencies of university students according to high school graduation type variable, no significant difference was found between the groups. In the study of Kutlu, Gökdere \& Çakır (2015), it is determined that there is a significant difference between those who graduated from general high school and those who graduated from Anatolian High School / Anatolian Teacher High School of the tendency of academic suspension according to the high school students graduated from university students. The researchers interpreted this results in a manner that the students who graduated from the high school who have been admitted with the exam showed more academic suspension behavior than the students who graduated 
from the high school who have not been admitted with the exam. In Sarıoglu's (2011) research, academic suspension trends of Anatolian high school graduate students were higher than other high school graduate students' academic suspencion tendencies. Whereas Yiğit and Dilmaç (2015), on their researches on high school students, have set the tendency of academic suspension from high to low as general high school, Anatolian high school and vocational high school. Çelikkaleli and Akbay (2013) did not find any significant difference between graduated high school type and academic suspension tendencies. These findings do not coincide with the outcome of the research.

As a result of the analysis aimed to reveal the difference of academic suspension tendencies of university students according to the parents' occupational variables, no significant difference was found between the groups. In the study of Eksi and Dilmaç (2011), they found no significant difference between the profession of parents. This finding is in parallel with the research result.

As a result of the analysis aimed to reveal the difference of academic suspension tendencies of university students according to doing sports actively, no significant difference was found between the groups. In the study of Eksi and Dilmaç (2011), Students' doing or not doing sports actively is not affecting academic suspension behavior.

Findings obtained from this research reveal that the students of Faculty of Sports Sciences showed more academic suspension behaviors than the students of Faculty of Education. This can be interpreted as the fact that the students at the School of Sports Sciences are a bit more confident, passing lesson, being successful, and having less job search concerns after graduation.

Academic suspension behavior is one of the serious problems that prevent students from showing their true performance in universities. This finding indicates that the research findings revealing that there is a significant negative correlation between academic procrastination and academic achievement consistent with the research findings revealing that academic success predicts academic procrastination in high school students (Owens \& Newbegin, 1997).

At this point, interventions can be made to change students' unrealistic thoughts in psychological counseling services offered at universities. Also self-regulation in the guidance services to be given, self-control, effective use of time, and support for efficient course work will contribute to the prevention of academic suspension problem and the increase in success. Qualitative research can also be carried out to reveal the reasons for the academic suspension behavior of university students.

\section{References}

Akdoğan, A. (2013). Farkl depresyon anksiyete stres düzeylerine sahip üniversite ögrrencilerinin akademik erteleme davranışlarının incelenmesi. (Yayımlanmamış Yüksek Lisans Tezi). Necmettin Erbakan Üniversitesi/ Eğitim Bilimleri Enstitüsü, Konya.

Akkaya, E. (2007). Academic procrastination among faculty of education students: The role of gender, age, academic achievement, perfectionism and depression. (Yayımlanmamış Yüksek Lisans Tezi). Orta Doğu Teknik Üniversitesi/Sosyal Bilimler Enstitüsü, Ankara.

Arslan, A. (2013). Lise ögrrencilerinin akademik erteleme davranışlarının karar verme stilleri ile ilişkisi. (Yüksek Lisans Tezi). Gaziantep Üniversitesi/Eğitim Bilimleri Enstitüsü, Gaziantep.

Aydoğan, D. (2008). Akademik erteleme davranışının benlik saygısl, durumluk kaygı ve öz yeterliliği ile açıklanabilirliği. (Yayınlanmamış Yüksek Lisans Tezi). Gazi Üniversitesi/ Eğitim Bilimleri Enstitüsü, Ankara.

Aydoğan, D., \& Özbay, Y. (2012). Akademik erteleme davranışının benlik saygısı, durumluluk kaygı, öz-yeterlilik açısından açıklanabilirliğinin incelenmesi. Pegem Ĕ̆itim ve Öğretim Dergisi, 2(3).

Balkıs, M. (2006). Öğretmen Adaylarının Davranışlarındaki Erteleme Eğiliminin, Düşünme ve Karar Verme Tarzları İle İlişkisi. (Yayımlanmamış Doktora Tezi). Dokuz Eylül Üniversitesi/Eğitim Bilimleri Enstitüsü, İzmir.

Balkıs, M. (2007). Öğretmen adaylarının davranışlarındaki erteleme eğiliminin, karar verme stilleri ile ilişkisi. Pamukkale Üniversitesi Eğitim Fakültesi Dergisi, 1, 67-83.

Balkıs, M. (2013). Academic procrastination, academic life satisfaction and academic achievement: The mediation role of rational beliefs about studying. Journal of Cognitive and Behavioral Psychotherapies, 13(1), 57-74.

Balkıs, M., \& Duru, E. (2009). Prevalence of academic procrastination behavior among preservice teachers, and its relationship with demographic and individual preference. Journal of Theory and Practice in Education, 5(1), $18-32$. 
Baumeister, R. F., Heatherton, T. F., \& Tice, D. M. (1994). Losing control: How and why people fail at self-regulation. Academic press.

Beck, B. L., Koons, S. R., \& Milgram, D. L. (2000). Correlates and consequences of behavioral procrastination: The effects of academic procrastination, selfconsciousness, self-esteem and self-handicapping. Journal of Social Behavior \& Personality, 15(5), 3-13.

Berber Çelik, B., \& Odacı, H. (2015). Akademik Erteleme Davranışının Bazı Kişisel ve Psikolojik Değişkenlere Göre Açıklanması. Hacettepe Üniversitesi Eğitim Fakültesi Dergisi, 30(3), 31-47.

Beswick, G., Rothblum, E. D., \& Mann, L. (1988). Psychological antecedents of student procrastination. Australian Psychologist, 23(2), 207-217. https://doi.org/10.1080/00050068808255605

Burka, J. B., \& Yuen, L. M. (2008). Procrastination: Why you do it, what to do about it now. Da Capo Press.

Çakıcı, D. Ç. (2003). Lise ve üniversite ögrencilerinde genel erteleme ve akademik erteleme davranışının incelenmesi. (Yayınlanmamış yüksek lisans tezi) Ankara Üniversitesi, Ankara.

Çelikkaleli, Ö., \& Akbay, S. E. (2013). Üniversite Öğrencilerinin Akademik Erteleme Davranışı, Genel Yetkinlik İnancı ve Sorumluluklarının İncelenmesi. Ahi Evran Üniversitesi Kırşehir Eğitim Fakültesi Dergisi (KEFAD), S. 14(2), 237-254.

Ekşi, H., \& Dilmaç, B. (2011). Üniversite öğrencilerinin genel erteleme, karar vermeyi erteleme ve akademik erteleme düzeylerinin sürekli kaygı açısından incelenmesi. Uludă̆ Üniversitesi Eğitim Fakültesi Dergisi, 23(2), 433-450.

Ellis, A., \& Knaus, W. J. (1979). Overcoming procrastination: or, how to think and act rationally in spite of life's inevitable hassles. Signet.

Ferrari, J. R., Johnson, J. L., \& McCown, W. G. (1995). Procrastination and task avoidance: Theory, research, and treatment. Springer Science \& Business Media. https://doi.org/10.1007/978-1-4899-0227-6

Ferrari, J. R., O'Callaghan, J., \& Newbegin, I. (2005). Prevalence of procrastination in the United States, United Kingdom, and Australia: Arousal and avoidance delays among adults. North American Journal of Psychology, 7(1), 1-6.

Ferrari, J.R., \& Scher, S.J. (2000). Toward an understanding of academis and nonacademic tasks procrastinated by students: The use of daily logs. Psychology in the Schools, 37(4), 359-366. https://doi.org/10.1002/1520-6807(200007)37:4\%3C367::AID-PITS7\%3E3.0.CO;2-Y

Flett, G.L., Blankstein, K.R., Hewitt, P.L., \& Koledin, S. (1992). Components of perfectionism and procrastination in college students. Journal of Social Behavior and Personality, 20(2), 85-94. https://doi.org/10.2224/sbp.1992.20.2.85

Jackson, C. (2002). Laddishness" as a self- worth protection strategy. Gender and Education, 14, 37-51. https://doi.org/10.1080/09540250120098870

Jackson, C. (2003). Motives for "Laddishness" at school: fear of failure and fear of the "feminine". British Educational Research Journal, 29, 583-598. https://doi.org/10.1080/01411920301847

Kachgal, M. M., Hansen, L. S., \& Nutter, K. J. (2001). Academic procrastination prevention/intervention: Strategies and recommendations. Journal of Developmental Education, 25(1), 14-24.

Kandemir, M. (2010). Akademik ertelemeyi açıklayıcı bir model. (Yayınlanmamış doktora tezi). Gazi Üniversitesi, Ankara.

Karabıyık-Çeri, B., Çavuşoğlu, C., \& Gürol, M. (2015). Üniversite öğrencilerinin akademik erteleme düzeylerinin incelenmesi. The Journal of Academic Social Science Studies, 34, 385-394.

Karakitapoğlu-Aygün, Z. (2004). Self, identity, and emotional well- being among Turkish university students. The Journal of Psychology, 138(5), 457-478. https://doi.org/10.3200/JRLP.138.5.457-480

Kim, K. R., \& Seo E. H. (2015). The relationship between procrastination and academic performance: A meta-analysis. Personality and Individual Differences, 82, 26-33. https://doi.org/10.1016/j.paid.2015.02.038

Kutlu, N., Gökdere, M., \& Çakır, R. (2015). Öğretmen Adaylarının Akademik Erteleme Davranışı İle Öğretmenlik Mesleğine İliş̧kin Tutumlarının Karşılaştırmalı İncelemesi. K. Ü. Kastamonu Eğitim Dergisi, 23(3), 1311-1330.

Lay, C. H. (1986). At last, my research article on procrastination. Journal Of Research In Personality, 20(4), 474-495. 
https://doi.org/10.1016/0092-6566(86)90127-3

McCown, W., \& Roberts, R. (1994). A study of academic and work-related dysfunctioning relevant to college version of an indirect measure of impulsive behavior. Integra Technical Paper, 28-94.

Milgram, N. A., Gehrman, T., \& Keinan, G. (1992). Procrastination and emotional upset: A typological model. Personality and Individual Differences, 13(12), 1307-1313. https://doi.org/10.1016/0191-8869(92)90173-M

Motie, H., Heidari, M., \& Sadeghi, M. A. (2012). Predicting academic procrastination during self-regulated learning in Iranian first grade high school students. Procedia-Social and Behavioral Sciences, 69, 2299-2308. https://doi.org/10.1016/j.sbspro.2013.02.023

Neenan, M. (2008). Tackling procrastination: An REBT perspective for coaches. Journal of Rational-Emotive \& Cognitive-Behavior Therapy, 26(1), 53-62. https://doi.org/10.1007/s10942-007-0074-1

Owens, A. M., \& Newbegin, I. (1997). Procrastination in high school achievement: A causal structural model. Journal of Social Behavior \& Personality, 12(4), 869-887.

Pala, A., Akyıldız, M., \& Bağcı, C. (2011). Academic procrastination behaviour of preservice teachers' of Celal Bayar University. Procedia-Social and Behavioral Sciences, 29, 1418-1425. https://doi.org/10.1016/j.sbspro.2011.11.381

Prohaska, V., Morrill, P., Atiles, I., \& Perez, A. (2000). Academic procrastination by nontraditional students. Journal of Social Behavior \& Personality, 15(5), 125-135.

Rosario, P., Costa, M., Nunez, J.C., \& Gonzales-Pienda, J. (2009). Academic procrastination: Associations with personal, school, and family variables. The Spanish Journal of Psychology, 12(1), 118-127. https://doi.org/10.1017/S1138741600001530

Rothblum, E. D., Solomon, L. J., \& Murakami, J. (1986). Affective, cognitive, and behavioral differences between high and low procrastinators. Journal of Counseling Psychology, 33(4), 387. https://doi.org/10.1037/0022-0167.33.4.387

Saddler, C. D., \& Sacks. (1993). Multidimensional perfectionism and academic procrastination: relationships with depression in university students. Psychological Reports, 73, 863-871. https://doi.org/10.2466/pr0.1993.73.3.863

Sarığlu, A. F. (2011). Öğretmen Adaylarının Akademik Erteleme Eğilimi İle Mükemmeliyetçilik Düzeyleri Arasındaki İlişkinin İncelenmesi. (Yayınlanmamış Yüksek Lisans Tezi). İstanbul Üniversitesi/Sosyal Bilimler Enstitüsü, İstanbul.

Semb, G., Glick, D. M., \& Spencer, R. E. (1979). Student withdrawals and delayed work patterns in self-paced psychology courses. Teaching of Psychology, 6(1), 2325. https://doi.org/10.1207/s15328023top0601_8

Senecal, C., Koestner, R., \& Vallerand, R. J. (1995). Self-regulation and academic procrastination. Journal of Social Psychology, 135(1), 607-619. https://doi.org/10.1080/00224545.1995.9712234

Senecal, C., Lavoie, K., \& Koestner, R. (1997). Trait and situational factors in procrastination: An interactional model. Journal of Socifal Behavior \& Personality, 12(4), 889-903.

Sharma, M., \& Kaur, G. (2011). Gender differences in procrastination and academic stress among adolescents. Indian Journal of Social Science Researches, 8(12), 122-127.

Solomon, L. J., \& Rothblum, E. D. (1984). Academic procrastination: Frequency and cognitive-behavioral correlates. Journal of Counseling Psychology, 31, 503. https://doi.org/10.1037/0022-0167.31.4.503

Teyfur, M., Akpunar, B., Safalı, S., \& Ercengiz, M. (2017). Eğitim fakültesi öğrencilerin akademik erteleme davranışları ile sosyal medya bağımlılı̆̆ı arasındaki ilişkinin farklı değişkenler açısından incelenmesi. Turkish Studies, 12(33), 625-640. https://doi.org/10.7827/TurkishStudies.12558

Tice, D. M., \& Baumeister, R. F. (1997). Longitudinal study of procrastination, performance, stress, and health: The costs and benefits of dawdling. Psychological Science, 8(6), 454-458. https://doi.org/10.1111/j.1467-9280.1997.tb00460.x

Uzun Ozer, B. (2005). Academic procrastination: Prevalence, sef-reported reasons, gender difference and it's relation with academic achievement. (Yayınlanmamış yüksek lisans tezi). Ortadoğu Teknik Üniversitesi, Ankara. 
Uzun Özer, B., \& Topkaya, N. (2011). Akademik Erteleme ve Sınav Kaygısı. Adnan Menderes Üniversitesi Eğitim Fakültesi Eğitim Bilimleri Dergisi, 2(2), 12-19.

Watson, D. C. (2001). Procrastination and the five-factor model: A facet level analysis. Personality and Individual Differences, 30, 149-158. https://doi.org/10.1016/S0191-8869(00)00019-2

Yeşil, R., \& Şahan, E. (2012). Öğretmen adaylarının akademik işlerini erteleme nedenleri. Abant İzzet Baysal Üniversitesi Eğitim Fakültesi Dergisi, 12(2), 219-236.

Yiğit, R., \& Dilmaç, B. (2015). Ortaöğretimde öğrencilerinin sahip oldukları insani değerler ile akademik erteleme davranışlarının bazı değişkenler açısından incelenmesi. Dumlupınar Üniversitesi Sosyal Bilimler Dergisi, $31(31)$.

Zakeri, H., Esfahani, B.N., \& Razmjoee, M. (2013). Parenting styles and academic procrastination. Procedia - Social and Behavioral Sciences, 84, 57-60. https://doi.org/10.1016/j.sbspro.2013.06.509 